JOURNAL OF PUBLIC HEALTH INOVATION,

VOL. 01 NO.02. JUNI 2021

DOI: $10.34305 /$ JPHI.V1I2.279
Ciptaan disebarluaskan di bawah

Lisensi Creative CommonsAtribusi-

NonKomersial-BerbagiSerupa 4.0

Internasional.

\title{
FAKTOR-FAKTOR YANG BERHUBUNGAN DENGAN POSTPARTUM BLUES DI WILAYAH KERJA UPTD PUSKESMAS KADUGEDE
}

\author{
Nurul Hikmah, Anggit Kartikasari, Russiska, Noviyani \\ STIKes Kuningan \\ nurulhikmah128@gmail.com
}

\begin{abstract}
Abstrak
Postpartum blues adalah salah satu gangguan psikologi sementara ibu yang ditandai dengan memuncaknya emosi yang sering terjadi pada minggu pertama sehabis melahirkan, dimana suasana hati yang sangat utama merupakan kebahagiaan tetapi emosi ibu menjadi lebih labil. Tingkat pendidikan, jenis persalinan serta dukungan suami merupakan faktor yang mempengaruhi postpartum blues. Tujuan penelitian ini untuk mengidentifikasi faktor-faktor yang berhubungan dengan postpartum blues pada ibu nifas di wilayah kerja UPTD Puskesmas Kadugede. Jenis penelitian analitik dengan rancangan cross sectional. Teknik sampel dengan total sampling berjumlah 42 ibu nifas. Instrument berupa kuesioner. Analisis data univariat dan bivariate dengan menggunakan uji Chi-Square. Hasil analisis univariat sebagian besar ibu nifas di Wilayah Kerja UPTD Puskesmas Kadugede berpendidikan tingkat menengah $54,8 \%$, jenis persalinan spontan $81 \%$, mendapat dukungan suami 52,4\%. Hasil analisis bivariate didapatkan ada hubungan antara tingkat pendidikan dengan postpartum blues nilai $\rho=0,034$, tidak ada hubungan antara jenis persalinan dengan postpartum blues nilai $\rho=0,060$, ada hubungan antara dukungan suami dengan postpartum blues nilai $\rho=0,002$. Ibu nifas di Wilayah Kerja UPTD Puskesmas Kadugede diharapkan dapat meningkatkan pengetahuan mengenai pentingnya dukungan suami dalam memenuhi kebutuhan psikologis ibu untuk mencegah terjadinya postpartum blues.
\end{abstract}

Kata Kunci : :Tingkat pendidikan, dukungan suami, postpartum blues 
JOURNAL OF PUBLIC HEALTH INOVATION,

VOL. 01 NO.02. JUNI 2021

DOI: $10.34305 /$ JPHI.V1I2.279

\section{Pendahuluan}

Masa yang paling kritis dalam kehidupan ibu maupun bayi disebut masa nifas, diperkirakan terdapat $60 \%$ kematian ibu terjadi setelah persalinan dan 50\% kematian masa nifas terjadi dalam 24 jam pertama (Widyatun, 2012). Bidan dalam memberikan pelayanan kesehatan di masa nifas, memberikan asuhan keperawatan untuk memantau kondisi fisik, mental, spiritual dan sosial, serta tetap memberikan pendidikan dan konseling.

Menurut (Saleha, 2009), salah satu indikator derajat kesehatan suatu Negara adalah tingkat kematian ibu dan bayi. Hal ini berdampak besar pada keberhasilan pembangunan kesehatan. Untuk menurunkan angka kematian ibu dan bayi, masa nifas menjadi pertimbangan penting.

Tingkat pendidikan, jenis persalinan, dukungan suami, dan peningkatan kepekaan pasca persalinan erat kaitannya dengan masa nifas, sehingga diperlukan banyak penyesuaian pada minggu pertama atau satu bulan pasca persalinan, baik secara fisik maupun psikologis. Sebagian wanita berhasil menyesuaikan diri dengan baik, tetapi sebagian lainnya tidak berhasil menyesuaikan diri bahkan mengalami gangguan psikologis (Mansur, 2011).
Ciptaan disebarluaskan di bawah Lisensi Creative CommonsAtribusiNonKomersial-BerbagiSerupa 4.0 Internasional.

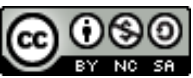

Postpartum blues adalah suatu gangguan psikologis sementara yang ditandai memuncaknya emosi ibu pada minggu pertama pasca melahirkan, suasana hati yang paling utama adalah kebahagiaan tetapi emosi ibu menjadi lebih labil (Saleha, 2009). Periode emosional stres yang terjadi antara hari ke-3 dan ke-10 setelah persalinan yang terjadi $80 \%$ pada ibu postpartum disebut postpartum blues (Bahiyatun. (2009), 2009).

Kejadian postpartum blues di beberapa negara berdasarkan penelitian Faisal-Cury, et al dalam Silaen, S. Misrawati Nurchahyati, 2014). yaitu Jepang sebanyak 15\%-50\%, Amerika Serikat sebanyak 27\%, Perancis sebanyak $31,7 \%$, Nigeria sebanyak $31,3 \%$ dan Yunani sebanyak 44,5\%. Prevalensi untuk Asia antara 26-85\%, dan prevalensi di Indonesia yaitu antara 50-70\% (Munawaroh dalam Silaen, S. Misrawati Nurchahyati, 2014).

Postpartum blues bisa terjadi pada semua ibu postpartum dari etnik dan ras manapun dan dapat dipengaruhi dari segi pendidikan, jenis persalinan serta dukungan suami. Menurut Freudenthal dalam Irawati, D. Yuliani, 2014), dari 63 persalinan caesar sebesar $25 \%$ ibu mengalami postpartum blues dan dari 52 persalinan normal hanya sebesar $8 \%$ yang mengalami postpartum 
JOURNAL OF PUBLIC HEALTH INOVATION,

VOL. 01 NO.02. JUNI 2021

DOI: $10.34305 /$ JPHI.V1I2.279

blues. Sedangkan menurut (Anggraini, D.R., \& Subakti, 2013), hasil penelitian menunjukan bahwa dari 18 responden yang mendapatkan dukungan negatif 14 diantaranya mengalami postpartum blues dan $4(22,2 \%)$ responden tidak postpartum blues, sedangkan dari 13 responden yang mengalami dukungan positif $10(76,9 \%)$ diantaranya tidak mengalami postpartum blues dan $3(23,1 \%)$ mengalami postpartum blues.

Perubahan psikologis mempunyai peranan yang sangat penting, pada masa postpartum ibu biasanya merasa sangat sensitif suasana hati paling utama biasanya bahagia namun emosinya sangat labil (Saleha, 2009). Postpartum blues masih dianggap sebagai kondisi wajar sehingga sering terabaikan dan tidak ditangani dengan baik, lebih lanjut tingkat keparahan gejala maupun dampak terjadinya depresi postpartum menjadikan gangguan ini tidak dapat diabaikan, terjadinya depresi postpartum dapat berdampak negatif pada ibu, perkembangan anak, hubungan perkawinan, serta hubungan dengan keseluruhan anggota keluarga (Iskandar dalam Rahmandani, A. Karyono. Dewi, E, 2012).

Hasil studi pendahuluan yang dilakukan terhadap 5 orang ibu nifas di
Ciptaan disebarluaskan di bawah

Lisensi Creative CommonsAtribusi-

NonKomersial-BerbagiSerupa 4.0

Internasional.
Wilayah Kerja UPTD Puskesmas Kadugede terdapat 3 orang yang tidak mendapatkan dukungan suami 1 orang bersalin secara sectio caesaria berpendidikan SMP dan 2 orang lainnya bersalin secara normal berpendidikan SD dan SMP, dari 3 orang yang tidak mendapatkan dukungan suami 2 orang diantaranya ibu primipara. Berdasarkan studi pendahuluan yang dilakukan dari 3 orang yang tidak mendapat dukungan suami 2 orang di antaranya mengalami postpartum blues 1 orang yang bersalin secara sectio caesarea atas indikasi berpendidikan SMP dan 1 orang lainnya bersalin secara spontan berpendidikan SD. Berdasarkan latar belakang di atas, maka peneliti tertarik melakukan penelitian mengenai "Faktor-Faktor yang Berhubungan dengan Postpartum Blues di Wilayah Kerja UPTD Puskesmas Kadugede".

\section{Metode}

Penelitian yang digunakan yaitu jenis penelitian analitik dengan pendekatan cross sectional. Menurut (Notoatmodjo, 2012), adalah suatu penelitian untuk mempelajari dinamika korelasi antara faktor-faktor risiko dengan efek, dengan cara pendekatan, observasi atau pengumpulan data sekaligus pada suatu 
JOURNAL OF PUBLIC HEALTH INOVATION,

VOL. 01 NO.02. JUNI 2021

DOI: $10.34305 /$ JPHI.V1I2.279

waktu (point time approach). Artinya setiap subjek penelitian diobservasi sekali saja dan pengukuran dilakukan terhadap status karakter atau variabel subjek pada saat dilakukan penelitian.

Menurut (Badriah, 2012), populasi didefinisikan sebagai kelompok subjek yang hendak dikenai generalisasi hasil penelitian. Sebagai suatu populasi, kelompok subjek tersebut harus memiliki ciri-ciri atau karakteristik bersama yang membedakannya dari kelompok subjek yang lain. Ciri tersebut dapat meliputi, ciri lokasi, ciri individu, atau juga ciri karakter tertentu. Adapun populasi dalam penelitian ini adalah seluruh ibu nifas di Wilayah Kerja UPTD Puskesmas Kadugede periode Mei-Juni tahun 2019 sebanyak 42 orang.

Menurut (Badriah, 2012), bahwa sampel adalah sebagian dari populasi karena sampel merupakan bagian dari populasi maka tentu memiliki ciri-ciri yang dimiliki populasinya.

Teknik sampling yang digunakan dalam penelitian ini adalah teknik total sampling. Menurut (Badriah, 2012), jika jumlah populasi kurang dari 30 maka semua populasi penelitian tersebut otomatis menjadi sampel penelitian. Dalam penelitian ini yang menjadi sampel adalah seluruh ibu nifas di Wilayah Kerja UPTD Puskesmas
Ciptaan disebarluaskan di bawah

Lisensi Creative CommonsAtribusi-

NonKomersial-BerbagiSerupa 4.0

Internasional.
Kadugede periode Mei-Juni tahun 2019 sebanyak 42 orang.

Menurut (Badriah, 2012), variabel bebas adalah suatu variabel yang variasinya mempengaruhi variabel lain. Pada penelitian ini yang dijadikan variabel bebas adalah tingkat pendidikan, jenis persalinan serta dukungan suami.

Menurut (Badriah, 2012), variabel terikat adalah variabel penelitian yang diukur untuk mengetahui besarnya efek dan pengaruh variabel lain. Pada penelitian ini yang dijadikan variabel terikat adalah postpartum blues.

Menurut (Badriah, 2012), instrumen adalah suatu alat pengumpulan data yang telah baku atau alat pengumpulan data yang memiliki standar validitas dan reliabilitas. Alat pengumpulan data yang digunakan dalam penelitian ini adalah kuesioner. Menurut (Arikunto, 2013), kuesioner merupakan sejumlah pertanyaan tertulis yang digunakan untuk memperoleh informasi dari responden dalam arti laporan tentang pribadinya, atau hal-hal yang ia ketahui. Kuesioner dalam penelitian ini untuk dukungan suami menggunakan kuesioner tertutup. Menurut (Hidayat, 2013), kuesioner tertutup dibuat sedemikian rupa sehingga responden hanya tinggal 
JOURNAL OF PUBLIC HEALTH INOVATION,

VOL. 01 NO.02. JUNI 2021

DOI: $10.34305 /$ JPHI.V1I2.279
Ciptaan disebarluaskan di bawah

Lisensi Creative CommonsAtribusi-

NonKomersial-BerbagiSerupa 4.0

Internasional. memilih atau menjawab pada jawaban yang

sudah ada.
Analisis Univariat

1. Gambaran tingkat pendidikan pada ibu nifas di Wilayah Kerja UPTD Puskesmas Kadugede.

Hasil

Tabel 5.1 Distribusi frekuensi tingkat pendidikan pada ibu nifas di Wilayah Kerja UPTD Puskesmas Kadugede

\begin{tabular}{cccc}
\hline No & Tingkat Pendidikan & Frekuensi (f) & Persentase\% \\
1. & Menengah & 23 & 54,8 \\
2. & Dasar & 19 & 45,2 \\
& Total & 42 & 100 \\
\hline
\end{tabular}

Sumber: Hasil Penelitian Tahun 2019

2. Gambaran jenis persalinan pada ibu nifas

Berdasarkan tabel 5.1 di atas di Wilayah Kerja UPTD Puskesmas menunjukkan bahwa dari 42 responden Kadugede.

sebagian besar berpendidikan menengah

sebanyak 23 responden $(54,8 \%)$.

Tabel 5.2 Distribusi frekuensi jenis persalinan pada ibu nifas di Wilayah Kerja UPTD Puskesmas Kadugede

\begin{tabular}{cccc}
\hline No & Jenis Persalinan & Frekuensi (f) & Persentase \% \\
1. & Spontan & 34 & 81,0 \\
2. & Buatan & 8 & 19,0 \\
\multicolumn{2}{r}{ Total } & 42 & 100 \\
\hline
\end{tabular}

Sumber: Hasil Penelitian Tahun 2019

Berdasarkan tabel 5.2 di atas menunjukkan bahwa dari 42 responden sebagian besar mengalami jenis persalinan spontan sebanyak 34 responden $(81,0 \%)$.
3. Gambaran dukungan suami pada ibu nifas di Wilayah Kerja UPTD Puskesmas Kadugede.

Tabel 5.3 Distribusi frekuensi dukungan suami pada ibu nifas di Wilayah Kerja UPTD Puskesmas Kadugede

\begin{tabular}{clcc}
\hline No & Dukungan Suami & Frekuensi (f) & Persentase \% \\
1. & Mendukung & 22 & 52,4 \\
2. & Tidak Mendukung & 20 & 47,6 \\
& Total & 42 & 100 \\
\hline
\end{tabular}

Sumber : Hasil Penelitian Tahun 2019 
JOURNAL OF PUBLIC HEALTH INOVATION,

VOL. 01 NO.02. JUNI 2021

DOI: $10.34305 /$ JPHI.V1I2.279
Ciptaan disebarluaskan di bawah

Lisensi Creative CommonsAtribusi-

NonKomersial-BerbagiSerupa 4.0

Internasional.
Berdasarkan tabel 5.3 menunjukan bahwa dari 42 responden sebagian besar mendapat dukungan suami yaitu sebanyak
4. Gambaran postpartum blues pada ibu nifas di Wilayah Kerja UPTD Puskesmas Kadugede.

22 responden $(52,4 \%)$.

Tabel 5.4 Distribusi frekuensi postpartum blues pada ibu nifas di Wilayah Kerja UPTD Puskesmas Kadugede.

\begin{tabular}{cccc}
\hline No & Postpartum Blues & Frekuensi (f) & Persentase \% \\
1. & Postpartum Blues & 19 & 45,2 \\
2. & Tidak Postpartum Blues & 23 & 54,8 \\
& Total & 42 & 100 \\
\hline
\end{tabular}

Sumber: Hasil Penelitian Tahun 2019

Analisis Bivariat

Berdasarkan tabel 5.4 menunjukan

1. Hubungan tingkat pendidikan dengan bahwa dari 42 responden sebagian besar tidak mengalami postpartum blues yaitu sebanyak 23 responden $(54,8 \%)$. postpartum blues pada ibu nifas di Wilayah Kerja UPTD Puskesmas Kadugede.

Tabel 5.5 Hubungan tingkat pendidikan dengan postpartum blues pada ibu nifas di Wilayah Kerja UPTD Puskesmas Kadugede

\begin{tabular}{|c|c|c|c|c|c|c|c|c|}
\hline \multirow{3}{*}{ Tingkat Pendidikan } & \multicolumn{4}{|c|}{ Postpartum Blues } & \multirow{2}{*}{\multicolumn{2}{|c|}{ Total }} & \multirow{3}{*}{$\mathbf{O R}$} & \multirow{3}{*}{ P value } \\
\hline & \multicolumn{2}{|c|}{$\begin{array}{l}\text { Postpartum } \\
\text { Blues }\end{array}$} & \multicolumn{2}{|c|}{$\begin{array}{c}\text { Tidak } \\
\text { Postpartum } \\
\text { Blues }\end{array}$} & & & & \\
\hline & $\mathbf{f}$ & $\%$ & $\mathbf{F}$ & $\%$ & $\mathbf{f}$ & $\%$ & & \\
\hline Menengah & 7 & 30,4 & 16 & 69,6 & 23 & 100 & & \\
\hline Dasar & 12 & 63,2 & 7 & 36,8 & 19 & 100 & 0,255 & 0,034 \\
\hline
\end{tabular}

Berdasarkan tabel 5.5 menunjukan bahwa dari 23 responden yang berpendidikan tingkat menengah mayoritas tidak mengalami postpartum blues sebanyak 16 responden $(69,6 \%)$, dari 19 responden yang berpendidikan tingkat dasar mayoritas mengalami postpartum blues sebanyak 12 responden $(63,2 \%)$. Berdasarkan uji ChiSquare diperoleh nilai -value 0,034 berarti ada hubungan yang signifikan antara tingkat pendidikan dengan postpartum blues, dari hasil analisis diperoleh pula nilai OR yaitu 0,255 artinya ibu yang berpendidikan tingkat menengah bukan merupakan faktor resiko. 
JOURNAL OF PUBLIC HEALTH INOVATION,

VOL. 01 NO.02. JUNI 2021

DOI: $10.34305 /$ JPHI.V1I2.279
Ciptaan disebarluaskan di bawah

Lisensi Creative CommonsAtribusi-

NonKomersial-BerbagiSerupa 4.0

Internasional.

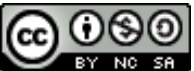

2. Hubungan jenis persalinan dengan

Wilayah Kerja UPTD Puskesmas postpartum blues pada ibu nifas di

Kadugede.

Tabel 5.6. Hubungan jenis persalinan dengan postpartum blues pada ibu nifas di Wilayah Kerja UPTD Puskesmas Kadugede

\begin{tabular}{|c|c|c|c|c|c|c|c|c|}
\hline \multirow{3}{*}{ Jenis Persalinan } & \multicolumn{4}{|c|}{ Postpartum Blues } & \multirow{2}{*}{\multicolumn{2}{|c|}{ Total }} & \multirow{3}{*}{ OR } & \multirow{3}{*}{$P$ value } \\
\hline & \multicolumn{2}{|c|}{$\begin{array}{l}\text { Postpartum } \\
\text { Blues }\end{array}$} & \multicolumn{2}{|c|}{$\begin{array}{c}\text { Tidak } \\
\text { Postpartum } \\
\text { Blues }\end{array}$} & & & & \\
\hline & $\mathbf{f}$ & $\%$ & $\mathbf{f}$ & $\%$ & $\mathbf{f}$ & $\%$ & & \\
\hline Spontan & 13 & 38,2 & 21 & 61,8 & 34 & 100 & & \\
\hline Buatan & 6 & 75,0 & 2 & 25,0 & 8 & 100 & 0,206 & 0,060 \\
\hline
\end{tabular}

Berdasarkan tabel 5.6 menunjukan bahwa dari 34 responden yang bersalin secara spontan mayoritas tidak mengalami postpartum blues sebanyak 21 responden $(61,8 \%)$, dari 8 responden yang bersalin secara buatan mayoritas mengalami postpartum blues sebanyak 6 responden (75,0\%). Berdasarkan uji Chi-Square diperoleh nilai -value 0,060 berarti tidak ada hubungan yang signifikan antara jenis persalinan dengan postpartum blues, dari hasil analisis diperoleh pula nilai OR yaitu 0,206 artinya ibu yang melahirkan secara spontan bukan merupakan faktor resiko.

3. Hubungan dukungan suami dengan postpartum blues pada ibu nifas di Wilayah Kerja UPTD Puskesmas Kadugede

Tabel 5.7 Hubungan dukungan suami dengan postpartum blues pada ibu nifas di Wilayah Kerja UPTD Puskesmas Kadugede

\begin{tabular}{|c|c|c|c|c|c|c|c|c|}
\hline \multirow{4}{*}{ Dukungan Suami } & \multicolumn{4}{|c|}{ Postpartum Blues } & \multirow{3}{*}{\multicolumn{2}{|c|}{ Total }} & \multirow{4}{*}{ OR } & \multirow{4}{*}{ P value } \\
\hline & \multirow{2}{*}{\multicolumn{2}{|c|}{$\begin{array}{l}\text { Postpartum } \\
\text { Blues }\end{array}$}} & \multirow{2}{*}{\multicolumn{2}{|c|}{$\begin{array}{c}\text { Tidak } \\
\text { Postpartum } \\
\text { Blues }\end{array}$}} & & & & \\
\hline & & & & & & & & \\
\hline & f & $\%$ & $\mathbf{f}$ & $\%$ & $\mathbf{F}$ & $\%$ & & \\
\hline Mendukung & 5 & 22,7 & 17 & 77,3 & 22 & 100 & & \\
\hline Tidak Mendukung & 14 & 70.0 & 6 & 30.0 & 20 & 100 & 0,126 & 0,002 \\
\hline
\end{tabular}

Berdasarkan tabel 5.7 menunjukan bahwa dari 22 responden yang mendapat dukungan suami mayoritas tidak mengalami postpartum blues sebanyak 17 responden (77,3\%), dari 20 responden yang tidak mendapat dukungan suami mayoritas 
JOURNAL OF PUBLIC HEALTH INOVATION,

VOL. 01 NO.02. JUNI 2021

DOI: $10.34305 /$ JPHI.V1I2.279
Ciptaan disebarluaskan di bawah

Lisensi Creative CommonsAtribusi-

NonKomersial-BerbagiSerupa 4.0

Internasional. mengalami postpartum blues sebanyak 14 responden (70.0\%). Berdasarkan uji ChiSquare diperoleh nilai -value 0,002 berarti ada hubungan yang signifikan antara dukungan suami dengan postpartum blues, dari hasil analisis diperoleh pula nilai OR yaitu 0,126 artinya ibu yang mendapat dukungan suami bukan merupakan faktor resiko.

\section{Pembahasan}

Analisis Univariat

Berdasarkan tabel 5.1 menunjukan bahwa dari 42 responden sebagian besar berpendidikan menengah sebanyak 23 responden $(54,8 \%)$ dan berpendidikan dasar sebanyak 19 responden $(45,2 \%)$. Hal ini sesuai dengan pendapat (Warsini, 2015), semakin tinggi tingkat pendidikan seseorang maka akan semakin mudah menerima informasi yang pada akhirnya akan mempengaruhi perilaku seseorang. Pendidikan merupakan proses memberikan pengaruh pada kebiasaan, tingkah laku, pikiran dan perasaan seseorang, pada dasarnya pendidikan dilakukan untuk menuju kesempurnaan (Malik dalam Warsini, 2015)

Berdasarkan analisis peneliti mayoritas responden di Wilayah Kerja UPTD Puskesmas Kadugede berpendidikan tingkat menengah sebanyak 23 responden, hal ini disebabkan karena mayoritas masyarakat di wilayah tersebut sudah memahami pentingnya pendidikan dan didukung pula oleh fasilitas yang sudah memadai, sarana prasarana yang mendukung, transportasi memadai dan sekolah yang mudah dijangkau.

Berdasarkan tabel 5.2 menunjukan bahwa dari 42 responden sebagian besar melahirkan secara spontan sebanyak 34 responden $(81,0 \%)$ dan 8 responden $(19.0 \%)$ melahirkan secara secara sectio caesaria. Hal ini sejalan dengan penelitian Permatasari (2012), didapatkan sebanyak 31 ibu melahirkan secara spontan (46,97\%), dan 35 ibu melahirkan secara tindakan $(53,03 \%)$ yang terdiri dari 33 ibu melahirkan secara sectio caesarea dan 2 ibu melahirkan dengan vacum. Ibu yang melahirkan secara caesar cenderung mengalami depresi dibandingkan dengan ibu yang melahirkan secara normal.

Persalinan merupakan proses pengeluaran hasil konsepsi yang dapat hidup dari dalam uterus melalui vagina atau jalan lain. Dikatakan persalinan normal apabila bayi lahir dengan letak belakang kepala tanpa memakai alat atau pertolongan istimewa serta tidak melukai ibu dan bayi, dan pada umumnya berlangsung kurang dari 
JOURNAL OF PUBLIC HEALTH INOVATION,

VOL. 01 NO.02. JUNI 2021

DOI: $10.34305 / J P H I . V 1 I 2.279$

24 jam (Prawirohardjo dalam Priyanti, 2013).

Berdasarkan analisis peneliti mayoritas responden di Wilayah Kerja UPTD Puskesmas Kadugede dari 42 responden mayoritas melahirkan secara normal sebanyak 34 responden hal ini disebabkan karena responden beranggapan bahwa bersalin secara normal akan lebih cepat dalam proses penyembuhannya dibandingkan dengan persalinan secara caesarea. Selain itu, 8 responden yang melahirkan secara caesar mayoritas diantara mereka atas indikasi.

Berdasarkan tabel 5.3 menunjukan bahwa dari 42 responden sebagian besar mendapat dukungan suami yaitu sebanyak 22 responden $(52,4 \%)$ dan yang tidak mendapat dukungan suami sebanyak 20 responden $(47,6 \%)$. Hal ini sejalan dengan penelitian (Fatimah, 2009), bahwa dari 25 responden 4 orang $(16 \%)$ mendapat dukungan suami kurang, 15 orang (60\%) mendapat dukungan suami sedang dan 6 orang (24\%) mendapat dukungan suami tinggi.

Dalam memberi kekuatan tersendiri bagi ibu postpartum maka dukungan suami sangat penting diberikan dan tidak dapat diremehkan serta tidak kalah penting membangun suasana positif, dimana istri
Ciptaan disebarluaskan di bawah

Lisensi Creative CommonsAtribusi-

NonKomersial-BerbagiSerupa 4.0

Internasional.

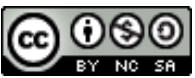

merasakan hari-hari pertama yang melelahkan oleh sebab itu dukungan dan sikap positif dari pasangan dan keluarga akan memberi kekuatan tersendiri bagi ibu postpartum (Irawati, D. Yuliani, 2014).

Berdasarkan analisis peneliti mayoritas responden di Wilayah Kerja UPTD Puskesmas Kadugede 22 responden sudah mendapat dukungan dari suami, hal itu di dapat dari suami yang peduli dan membantu ibu dalam merawat bayinya dengan memberikan dukungan emosional yaitu suami menemani ibu ketika bayi menangis di malam hari, membantu mengerjakan pekerjaan rumah ketika ibu sedang menyusui bayinya, membiarkan ibu istirahat ketika sudah lelah mengurus bayinya seharian dan memotivasi ibu ketika ASI belum keluar. Selain itu, masih tingginya angka responden yang tidak mendapat dukungan suami yaitu sebanyak 20 responden, hal ini terjadi karena dukungan suami yang kurang optimal karena suami takut untuk membantu ibu dalam perawatan bayi, karena suami merasa bahwa lai-laki tidak mampu merawat bayi dengan baik dan suami beranggapan istri lebih mampu merawat bayinya dengan baik.

Berdasarkan tabel 5.4 menunjukan bahwa dari 42 responden sebagian besar tidak mengalami postpartum blues yaitu 
JOURNAL OF PUBLIC HEALTH INOVATION,

VOL. 01 NO.02. JUNI 2021

DOI: $10.34305 /$ JPHI.V1I2.279
Ciptaan disebarluaskan di bawah

Lisensi Creative CommonsAtribusi-

NonKomersial-BerbagiSerupa 4.0

Internasional. sebanyak 23 responden $(54,8 \%)$ dan yang mengalami postpartum blues sebanyak 19 responden $(54,8 \%)$. Berdasarkan penelitian (Priyanti, 2013), didapatkan data bahwa sebagian besar ibu nifas yang mengalami postpartum blues yaitu 46 responden $(61,8 \%)$ dari jumlah tersebut diketahui pada ibu nifas akan mengalami beberapa perubahan diantaranya perubahan psikologis, jika ibu nifas tidak menyesuaikan diri dengan perubahan tersebut maka ibu dapat mengalami postpartum blues.

Postpartum blues sering disebut sebagai suatu stres psikologis ringan pada wanita pasca persalinan. Periode ketidaknyamanan pada hari pertama atau kedua pasca melahirkan, ditandai dengan kebahagiaan yang luar biasa dan perasaan yang sangat sehat, namun selalu diikuti oleh periode kesedihan "blues" (Bobak dalam (Irawati, D. Yuliani, 2014).

Berdasarkan analisis peneliti mayoritas responden di Wilayah Kerja UPTD Puskesmas Kadugede masih tingginya angka kejadian postpartum blues yaitu sebanyak 19 responden hal ini mungkin disebabkan karena persalinan dapat menimbulkan stres bagi ibu dan merupakan peristiwa yang rumit yang mengakibatkan terjadinya postpartum blues.
Analisis Bivariat

Berdasarkan hasil uji Chi-Square diperoleh nilai -value yaitu 0,034 , dapat disimpulkan bahwa nilai -value lebih kecil dari nilai $\alpha$, sehingga Ha diterima artinya ada hubungan yang signifikan antara faktor tingkat pendidikan dengan postpartum blues, sedangkan jika dilihat dari nilai odd ratio (OR) didapat sebesar 0,255 artinya ibu yang berpendidikan tingkat menengah bukan merupakan faktor resiko.

Hasil penelitian ini sejalan dengan penelitian (Kurniasari, D. Astuti, Y, 2014), bahwa dari total 35 responden sebanyak 6 $(17,1 \%)$ mengalami postpartum blues yaitu responden yang berpendidikan rendah. Semakin tinggi tingkat pendidikan seseorang maka semakin baik pengetahuan ibu karena mendapat banyak informasi.

Berdasarkan analisis peneliti di Wilayah Kerja UPTD Puskesmas Kadugede yang mengalami postpartum blues mayoritas responden yang berpendidikan tingkat dasar dibandingkan tingkat menengah, hal ini disebabkan karena pendidikan seseorang dapat mempengaruhi cara berfikir serta cara pandang terhadap diri maupun lingkungan, oleh karena itu akan berbeda sikap responden yang mempunyai pendidikan tinggi dibandingkan dengan seseorang berpendidikan rendah dalam menyikapi 
JOURNAL OF PUBLIC HEALTH INOVATION,

VOL. 01 NO.02. JUNI 2021

DOI: $10.34305 /$ JPHI.V1I2.279

proses selama persalinan, sehingga pada pendidikan rendah lebih banyak ibu mengalami postpartum blues. Namun tidak menutup kemungkinan yang berpendidikan tingkat dasar tidak mengalami postpartum blues, ini dapat disebabkan adanya pengalaman sebelumnya sehingga ibu lebih bisa mengatasi dan menyikapi setiap proses setelah melahirkan dan mengurus bayinya.

Berdasarkan hasil uji Chi-Square diperoleh nilai -value yaitu 0,060, maka dapat disimpulkan bahwa nilai -value lebih besar dari nilai $\alpha$, sehingga $\mathrm{Ha}$ ditolak artinya tidak ada hubungan yang signifikan antara jenis persalinan dengan postpartum blues, sedangkan jika dilihat dari nilai odd ratio $(\mathrm{OR})$ didapat sebesar 0,206 artinya ibu yang melahirkan secara spontan bukan merupakan faktor resiko.

Hal ini sejalan dengan penelitian (Irawati, D. Yuliani, 2014) bahwa tidak terdapat hubungan yang bermakna antara jenis persalinan terhadap kejadian postpartum blues dengan nilai -value $(0,519)$, dari kedua cara persalinan baik secara sectio caesaria maupun secara spontan sebagian ibu postpartum mengalami postpartum blues, tetapi pada cara persalinan post sectio caesaria ibu yang mengalami postpartum blues lebih tinggi.
Ciptaan disebarluaskan di bawah

Lisensi Creative CommonsAtribusi-

NonKomersial-BerbagiSerupa 4.0

Internasional.

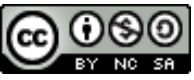

Suatu proses pengeluaran hasil konsepsi (janin dan plasenta) yang sudah cukup bulan, melalui jalan lahir (pervaginam), dengan kekuatan ibu sendiri atau tanpa bantuan disebut persalinan spontan (eutocia)

(Manuaba

dalam(Permatasari, 2012). Sedangkan proses persalinan yang berlangsung dengan bantuan tenaga dari luar disebut dengan persalinan buatan (Prawiroharjo dalam (Warsini, 2015).

Berdasarkan analisa peneliti di Wilayah Kerja UPTD Puskesmas Kadugede dari 34 responden yang bersalin secara spontan masih tingginya angka postpartum blues yaitu sebanyak 13 responden hal ini disebabkan karena beberapa faktor diantaranya paritas, kesiapan menjadi orang tua serta kurangnya dukungan yang optimal dari suami dan keluarga. Dari 8 responden yang melahirkan secara sectio caesaria 6 responden mengalami postpartum blues, hal ini karena ibu yang melahirkan secara sectio caesaria merasa bingung dan sedih terutama jika operasi tersebut dilakukan karena keadaan darurat atau atas indikasi.

Berdasarkan hasil uji Chi-Square diperoleh nilai -value yaitu 0,002, maka dapat disimpulkan bahwa nilai -value lebih kecil dari nilai $\alpha$, sehingga $\mathrm{Ha}$ diterima artinya ada hubungan yang signifikan antara 
JOURNAL OF PUBLIC HEALTH INOVATION,

VOL. 01 NO.02. JUNI 2021

DOI: $10.34305 /$ JPHI.V1I2.279
Ciptaan disebarluaskan di bawah

Lisensi Creative CommonsAtribusi-

NonKomersial-BerbagiSerupa 4.0

Internasional.

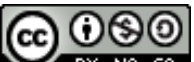

dukungan suami dengan postpartum blues, sedangkan jika dilihat dari nilai odd ratio (OR) didapat sebesar 0,126 artinya ibu yang mendapat dukungan suami bukan merupakan faktor resiko.

Hasil penelitian ini sesuai dengan penelitian (Irawati, D. Yuliani, 2014) yang menyatakan bahwa terdapat pengaruh dukungan suami dengan terjadinya postpartum blues dengan nilai p-value $(0,013)$. Dukungan suami tidak hanya berupa dukungan psikologis, tetapi istri juga membutuhkan dukungan fisik, evaluasi, informasi dan dukungan finansial. Oleh karena itu, dukungan yang diberikan merupakan paket lengkap yang membuat istri merasa nyaman dan dapat melahirkan dengan lancar.

Dukungan suami merupakan suatu bentuk interaksi sosial yang didalamnya terdapat hubungan saling memberi dan menerima bantuan yang nyata, bantuan semacam ini akan memungkinkan individu untuk berpartisipasi dalam sistem sosial yang akhirnya dapat memberikan kasih sayang, perhatian, dan sense of attachment yang baik pada pasangan, keluarga, serta social (Ingela dalam Irawati, D. Yuliani, 2014).

Berdasarkan analisa peneliti di Wilayah Kerja UPTD Puskesmas Kadugede dari 42 responden mayoritas responden yang mendapat dukungan suami sebanyak 22 responden namun dari 22 responden tersebut masih ada yang sudah mendapat dukungan suami namun mengalami postpartum blues yaitu sebanyak 5 responden, hal ini mungkin dikarenakan suami bekerja dan tidak dapat memberikan dukungan yang maksimal, suami hanya dapat melihat istrinya setelah pulang kerja dan kadang-kadang suami terlihat lebih lelah dan cenderung lebih banyak istirahat dan tidur daripada memberi perhatian kepada ibu dan bayinya. Selain itu, 20 responden yang tidak mendapat dukungan suami yang mengalami postpartum blues sebanyak 14 responden, hal ini disebabkan karena suami yang mayoritas bekerja di luar kota sehingga istri tidak mendapatkan dukungan dari suami ketika ibu melahirkan pun suami tidak mendampinginya.

\section{Kesimpulan}

Berdasarkan hasil penelitian terhadap 42 orang Ibu Nifas di Wilayah Kerja UPTD Puskesmas Kadugede, maka dapat disimpulkan sebagai berikut:

1. Sebagian besar ibu nifas di Wilayah Kerja UPTD Puskesmas Kadugede berpendidikan menengah sebanyak 23 responden $(54,8 \%)$. 
JOURNAL OF PUBLIC HEALTH INOVATION,

VOL. 01 NO.02. JUNI 2021

DOI: $10.34305 /$ JPHI.V1I2.279

2. Sebagian besar ibu nifas di Wilayah Kerja UPTD Puskesmas Kadugede mengalami jenis persalinan spontan sebanyak 34 responden $(81,0 \%)$.

3. Sebagian besar ibu nifas di Wilayah Kerja UPTD Puskesmas Kadugede mendapat dukungan suami yaitu sebanyak 22 responden $(52,4 \%)$.

4. Sebagian besar ibu nifas di Wilayah Kerja UPTD Puskesmas Kadugede tidak mengalami postpartum blues yaitu sebanyak 23 responden $(54,8 \%)$.

5. Ada hubungan antara tingkat pendidikan dengan postpartum blues pada ibu nifas dengan nilai $\square$-value 0,034 dan nilai OR 0,255 artinya ibu yang berpendidikan tingkat menengah bukan merupakan faktor resiko.

6. Tidak ada hubungan antara jenis persalinan dengan postpartum blues pada ibu nifas dengan nilai $\square$-value 0,060 dan nilai OR 0,206 artinya ibu yang melahirkan secara spontan bukan merupakan faktor resiko.

7. Ada hubungan antara dukungan suami dengan postpartum blues pada ibu nifas dengan nilai $\square$-value 0,002 dan nilai OR 0,126 artinya ibu yang mendapat dukungan suami bukan merupakan faktor resiko.
Ciptaan disebarluaskan di bawah

Lisensi Creative CommonsAtribusi-

NonKomersial-BerbagiSerupa 4.0

Internasional.

\section{Saran}

1. Bagi Ibu Nifas

Hasil penelitian ini diharapkan dapat menjadi sumber informasi mengenai pentingnya dukungan suami, sebab suami merupakan anggota keluarga ibu yang paling dekat dan lebih mengerti kebutuhan ibu yang sangat membutuhkan dukungan emosional dan fisik terutama pada saat masa nifas, hal ini bertujuan untuk mencegah terjadinya postpartum blues.

2. Bagi Bidan

Hasil penelitian ini diharapkan dapat menjadi bahan masukan bagi tenaga penyedia layanan kesehatan untuk dapat lebih memperhatikan kesehatan psikologis ibu pasca melahirkan dengan memahami dinamika terjadinya postpartum blues, gejala-gejala yang terjadi serta respon penanggulangan dan resiko yang mungkin terjadi.

3. Bagi Program Studi Diploma III Kebidanan

Hasil penelitian ini dapat dijadikan bahan informasi dan bahan referensi atau bacaan bagi peneliti lain di kemudian hari terutama untuk meneliti hal-hal yang belum terungkap dalam penelitian ini dan dijadikan dasar pemikiran dalam penelitian selanjutnya. 
JOURNAL OF PUBLIC HEALTH INOVATION,

VOL. 01 NO.02. JUNI 2021

DOI: $10.34305 /$ JPHI.V1I2.279
Ciptaan disebarluaskan di bawah

Lisensi Creative CommonsAtribusi-

NonKomersial-BerbagiSerupa 4.0

Internasional.

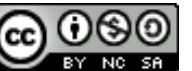

\section{Daftar Pustaka}

Anggraini, D.R., \& Subakti, Y. (2013). Kupas Tuntas Seputar Kehamilan. Agro Media Pustaka.

Arikunto, S. (2013). Prosedur Penelitian. Rineka Cipta.

Badriah, D. L. (2012). Metodologi Penelitian Ilmu-Ilmu Kesehatan. Multazam.

Bahiyatun. (2009). (2009). Asuhan Kebidanan Nifas Normal. EGC.

Fatimah. (2009). Dukungan Suami dengan Kejadian Postpartum Blues pada Ibu Primipara di Ruang Bougenville RSUD Tugurejo Semarang. Dukungan Suami dengan Kejadian Postpartum Blues pada Ibu Primipara di Ruang Bougenville RSUD Tugurejo Semarang eprints.undip.ac.id

Hidayat, A. A. A. (2013). Metode Penelitian Keperawatan dan Teknik Analisis Data. Jakarta: Salemba Medika.

Irawati， D. Yuliani, F. (2014). Pengaruh Faktor Psikososial dan Cara Persalinan Terhadap Terjadinya Postpartum Blues pada Ibu Nifas. Hospital Majapahit, $6(1-7)$.

Kurniasari, D. Astuti, Y, A. (2014). Hubungan antara Karakteristik Ibu Kondisi Bayi dan Dukungan Sosial Suami dengan Postpartum Blues pada Ibu dengan Persalinan SC di Rumah Sakit Umum Ahmad Yani Metro.

Mansur, H. (2011). Psikologi ibu dan Anak Untuk Kebidanan. Jakarta: Salemba Medika.
Notoatmodjo, S. (2012). Metodologi Penelitian Kesehatan. Jakarta: Rineka Cipta.

Permatasari, A. (2012). Hubungan Antara Pengetahuan Faktor Risiko Kehamilan dan Jenis Persalinan di RSUD DR.MOEWARDI.

Priyanti, S. (2013). Pengaruh Cara Persalinan Terhadap Terjadinya Postpartum Blues Di Rsud Ra. Basoeni Kabupaten Mojokerto.

Rahmandani, A. Karyono. Dewi, E, K. (2012). Strategi Penanggulangan (Coping) pada Ibu yang Mengalami Postpartum Blues di Rumah Sakit Umum Daerah Kota Semarang.

Saleha, S. (2009). Asuhan Kebidanan pada Masa Nifas. Jakarta: Salemba Medika.

Silaen, S. Misrawati Nurchahyati, S. (2014). Mekanisme Koping Ibu yang Mengalami Postpartum Blues.

Warsini. (2015). Hubungan antara Jenis Persalinan, Tingkat Pendidikan, Tingkat Pendapatan dan Status Bekerja Ibu dengan Keberhasilan ASI Eksklusif 6 (enam) bulan di Kecamatan Baki Kabupaten Sukoharjo.

Widyatun, D. (2012). Adaptasi Psikologis Ibu Masa Nifas. 